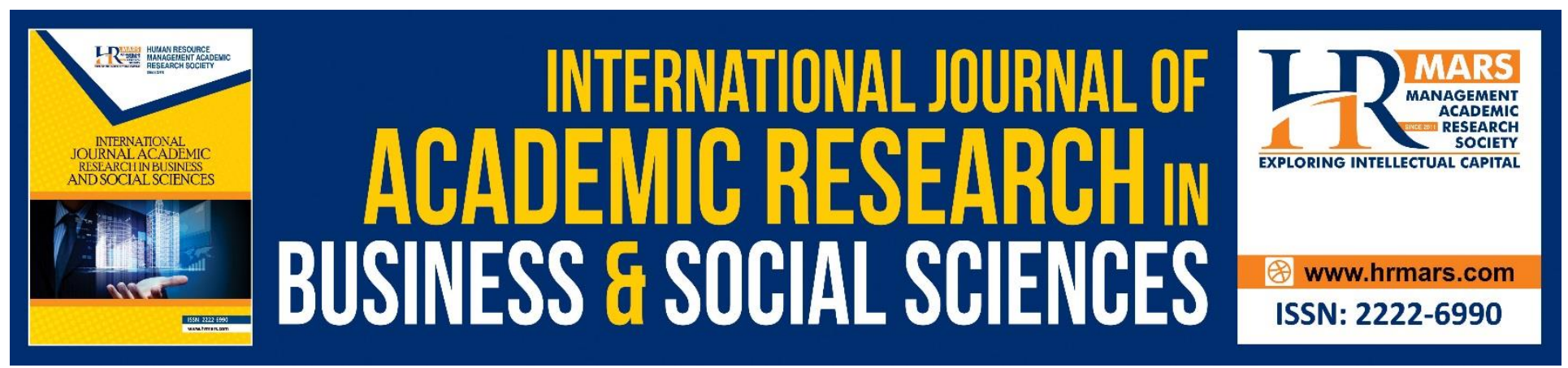

\title{
Flipped Classrooms in Teaching Method Courses at Universities
}

\section{Hamdi Serin \& Alfer Khabibullin}

To Link this Article: http://dx.doi.org/10.6007/IJARBSS/v9-i1/5459

DOI: $\quad 10.6007 /$ IJARBSS/v9-i1/5459

Received: 04 Jan 2019, Revised: 27 Jan 2019, Accepted: 10 Feb 2019

Published Online: 11 Feb 2019

In-Text Citation: (Serin \& Khabibullin, 2019)

To Cite this Article: Serin, H., \& Khabibullin, A. (2019). Flipped Classrooms in Teaching Method Courses at Universities. International Journal of Academic Research in Business and Social Sciences, 9(1), 573-585.

\section{Copyright: (c) 2019 The Author(s)}

Published by Human Resource Management Academic Research Society (www.hrmars.com)

This article is published under the Creative Commons Attribution (CC BY 4.0) license. Anyone may reproduce, distribute, translate and create derivative works of this article (for both commercial and non-commercial purposes), subject to full attribution to the original publication and authors. The full terms of this license may be seen at: http://creativecommons.org/licences/by/4.0/legalcode

Vol. 9, No. 1, 2019, Pg. 573 - 585

Full Terms \& Conditions of access and use can be found at http://hrmars.com/index.php/pages/detail/publication-ethics 


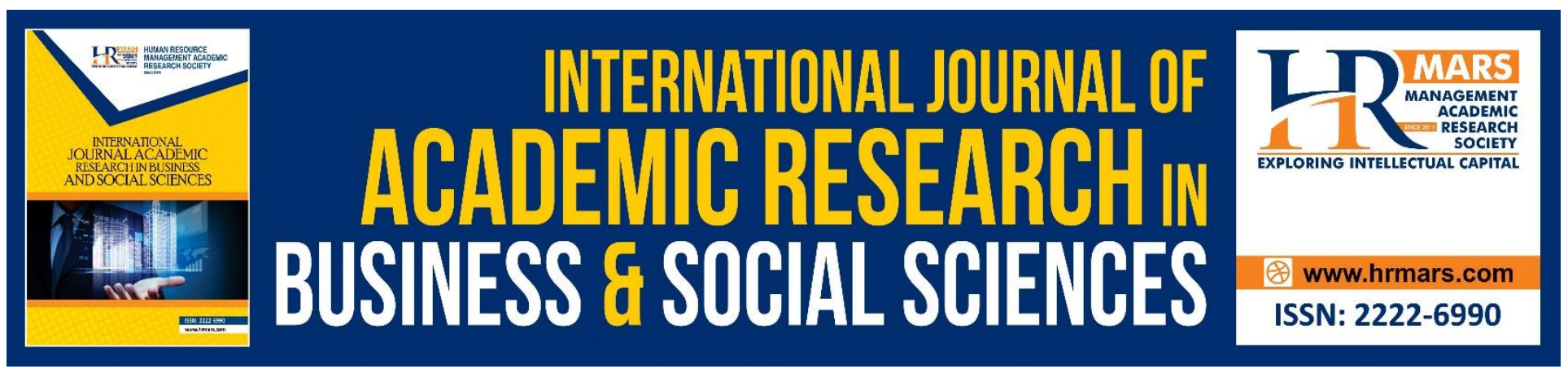

\title{
Flipped Classrooms in Teaching Method Courses at Universities
}

\author{
Hamdi Serin ${ }^{1} \&$ Alfer Khabibullin² \\ ${ }^{1}$ Department of Mathematic Education, Ishik University Erbil, Iraq \\ ${ }^{2}$ Department of English Language Teaching, Ishik University Erbil, Iraq \\ Correspondence: hamdi.serin@ishik.edu.iq, alfer.khabibullin@ishik.edu.iq
}

\begin{abstract}
The expectation from education is to bring 21st century learning skills to the new global and digital world students, as we the world progresses rapidly towards an information society. In this direction, learners should be able to create their own knowledge rather than just receive it; to be active in the learning process, and to discover new information and be able to transfer it. Developments in technology provide great opportunities for students to access and explore knowledge on their own. Together with these developments, the exploration for a learning environment, which will especially provide 21st century skills to students, is continuing. It can be said that the flipped classroom has important potential for students to gain 21st century skills. With the flipped classroom, the classroom time spent for the explanation of courses is moved out of the classroom, and it is aimed to also gets the students ' to use experience the application of such info/knowledge internalize the students' knowledge in practice during the class. In accordance with the flipped classroom model, this article aims at first, introducing the measurement and evaluation processes of suitable teaching methods, second, suggesting different activities inside and outside of the classroom, and, third, designing Web 2.0 applications that would help us realize the suggested method.
\end{abstract}

Keywords: 21st Century Skills, Flipped Classrooms, Teaching Methods, Web 2.0 Applications.

\section{Introduction}

Due to the general problems in the last years of Iraqi higher education, education is not given much importance. In this sense, the education curriculum needs to be renewed according to the needs and education technologies in Iraq. This renewal describes the 21st century learning skills of the International Association of Educational Technologies ([ISTE] 2008) as the skills and knowledge that must be learned in order to make learners of the rapidly increasing global and digital world live productively (Serin, 2015). Similarly, the Partnership for 21st Century Skills ([P21] 2009) defines these skills as skills, knowledge and expertise necessary for learners to successfully enter the business 
world. ISTE (2008) compiles these skills for learners under six main headings. These titles are; creativity and innovation, communication and collaboration, research and information literacy, critical thinking, problem solving and decision-making, digital citizenship, and finally, technological processes and concepts. P21 (2009) defines learning and innovation skills as the skills that students need to acquire while preparing for a complex life and business life, and it offers three different skills under this heading. These skills are; creativity and innovation, critical thinking and problem solving, communication and cooperation.

Rapid developments in technology accelerated searches for the developed learning environments. In recent years, behavioral learning applications have begun to switch to constructive learning practices (Temizyürek ve Ünlü, 2015). In this context, learning has evolved into a continuous action that has become independent of time and space. What expected from the teachers in this process is selfimprovement in the skills of using technology, linking activities in and out of school. What expected from the learners is knowledge production and synthesis (Taşkıran, Koral, \& Bozkurt, 2015). In addition, teachers should provide learners with 21st century skills as communication and cooperative work, knowledge-media and technology literacy, creative and critical thinking, problem solving, production, social and cultural skills development, learning to learn, self-organizing skills (Kotluk ve Kocakaya, 2015). In order to bring these skills to learners, a multi-application education should be provided by increasing the activities within the classroom. (Turan and Göktaş, 2015). The fact that the information is delivered to the students in different formats in a short period through more advanced technologies with similar functions is a sign that education continues its way with the traditional teaching-learning pedagogy that exists for a long time in the 21st century. However, when the technology is used appropriately, students can be provided with the learning environment in which they can organize knowledge themselves. In this direction, in particular with technological improvements in higher education, different approaches such as distance learning, blended learning and flipped classrooms have emerged as supporting or alternative to traditional classroom models. In short, providing students with creativity and innovation, critical thinking and problem solving, communication and cooperation skills is expected from 21st century education and teachers. In this direction, the faculties of education have come to an important position to maintain these skills, while training teachers.

\section{Flipped Classrooms}

It can be said that the Flipped Classrooms (FC) have existed in educational environments for many years. Teachers asking their students to read the unit related to the topic or to watch the videos about the topic before they arrive to the class, and the deeper structuring of the information in the class itself, may remind us flipped classrooms. Unlike all these associations, it can be shown that information technology is one of the basic elements in the course design and that it is used regularly and systematically throughout the teaching-learning process.

International names include "flipped classroom", "inverting the classroom", "reversed instruction", and the "Flipped Classroom" term is used in this article. Lage, Platt, and Treglia (2000) have given the concept of inverting the classroom to the audience, by stating that learning technologies, especially multitasking, offer students new possibilities for their own learning. Although FC is available in different forms in education for a long time, (Chen, Wang, Kinshuk and Chen, 2014; Strayer, 2012) 
first attracted attention as a result of Jonathan Bergmann and Aaron Sams, chemistry teachers at Woodland Park High School, recording videos of lectures for students who could not attend their courses and sharing them in an online environment (Tucker, 2012). In the course of these developments, the FC has begun to be considered as a new pedagogical approach (Bergmann and Sams, 2012).

FC, described as a renewed approach in education, is a pedagogical approach that, in the most general definition, suggests that learners learn lesson contents outside of the classroom and practice and do their homework inside it (Bliemel, 2014, Nerguizian, Mhiri, Mounier, Lemieux and Dahmane, 2014, Evseeva and Solozhenko, 2015, Obradovich, 2015). Students acquire the lesson content at home through videos, sound recordings, books, web sites and blogs, while in the classroom they perform related activities to reinforce the information and concepts they have already received (Bergmann and Sams, 2012, 2014; Bretzmann, 2013). Developing video recording software, digital media and interactive web pages allow the applicability of FC (Mason, Shuman and Cook, 2013). With these possibilities, students have more interactive and active role within the classroom as well as controlling learning time according to their own learning speeds (O'Flaherty and Philips, 2015).

\section{Teaching method lesson}

Although Teaching Method lesson is a common coded course in all of the teaching programs in the educational faculties, it is a course that deals with specific topics in the field and teaching-learning approaches. In all teaching programs, the main objective of this course is to supply candidates with the specific in the field methods and technical skills that are needed to plan teaching activities (Higher Education Council [YÖK], 2007). A Flipped Teaching method lesson is a concept that aims to teach different teaching methods and learning approaches to candidate teachers within the framework of developing technologies. One of the purposes of the Flipped Teaching method lesson for the candidate teachers is to design reliable learning environments according to the learners' needs and different circumstances and to integrate information and communication technologies effectively into teaching-learning processes.

\section{Fundamentals of the Flipped Process}

Teachers of the 21st century need to be individuals, who understand their students, learn in class activities and apply them in accordance with their skills, communicate effectively, use technology effectively, and have self-regulation skills (Darling Hammond, 2006). Therefore, teacher education programs should allow for a deeper internalization of knowledge and support the acquisition of learners' 21st century skills. O'Flaherty and Phillips (2015) point out that flipped classroom is a model with significant potential for learners to gain 21st century skills.

It is important to obtain directory from constructivist theory, when the teaching method lesson is designed according to the flipped classroom. In constructivist theory, it is better for learners to create knowledge rather than simply receive it (Von Glasersfeld, 1989), it is important for learners to discover and transfer definitions and concepts rather mechanical memorization (Dewey, 1980) and to be active participants in the natural social learning environments instead of being passive (Phillips, 1995). In this context, it can be said that the flipped classrooms have a high compatibility with constructivist learning theory. 


\section{Course Content and Structure}

The Flipped Teaching method course should consist one-year content. These contents should be determined in the curriculum in the flexible form of expert opinions based on the general objectives set for the course. According to general breakdowns, keeping in mind at the beginning that the learners of the content of the training are being educated for the first time with this teaching model, in order to obtain detailed information about the models the learners should have a "Flipped Classrooms Model". Features of the model should be presented to learners in terms of its use, superiority and limitations comparing to other learning method-techniques. In this term, it is possible to provide the teacher candidates with a model in which they can perform their teaching profession by using the technology intensively, and the complexity of the mind towards the process can be prevented.

"21st century skills" with general outlines should be presented in the course. With this content, candidate teachers can be informed about the characteristics of their future students as well as their conscious participation in the activities of the flipped lesson can be carried out. "Web 2.0 applications" should be presented in the following weeks. It is known that the technology knowledge of teachers is very important for information technologies and software courses together with all teaching fields. Nowadays, either requiring specific technologies or platform independent applications are widely used in education. Moreover, with each passing day, Web 2.0 applications that can be used in the field of education are being developed or updated. For all these reasons, it is important that candidate teachers identify these applications and know how to use them in their educational process. As the content of Web 2.0 applications is defined as four weeks course content, 13 different Web 2.0 applications can be introduced to candidate teachers and informed how to use them.

Flipped Teaching method lesson frame is specific to the field of teaching methods. For this reason, it is a necessity to keep the content of the "Teaching methods". When an instruction is designed, firstly the target audience and teaching facilities should be analyzed. From this point, after introducing the 21st century learning skills and the technologies that can be used in educational environments, special teaching methods specific to the area should be presented.

In the following weeks, it should be aimed to present the developments experienced in national education processes with the current learning approaches. For this reason, "Technology integration" topic should be discussed. After this aspect, it is aimed to introduce technology-oriented teaching models and approaches that prospective teachers can work in the process of technology integration. In the rest of the time, in order to move from simple to complex, "Mobile learning", "Virtual reality and enhanced reality" and "Playback" contents can be presented.

\section{Course Activities and Web 2.0 Applications}

Teaching method lesson activities are divided into two parts, in class and out of class. Three basic Web 2.0 applications were used for out of class activities. These applications are Edpuzzle, Edmodo and Facebook Groups. For the in-class activities, Facebook Groups were used to share different Web 2.0 applications and products depending on the topic of the week. 


\section{Web 2.0 Applications used Out of Class Activities and their Usage Objectives Edpuzzle}

Edpuzzle is a platform where we can add voice notes, open-ended or multiple-choice questions, and interactive course content to the video clips we have created or video that is available on platforms such as Youtube, Khan Academy. This platform allows students to see how many times they watched the videos, how many times they watched, and the answers they gave to the questions, and the students had the opportunity to learn at their own pace. Lesson videos prepared by the instructor should be uploaded to the Edpuzzle platform three days before lesson so that the students will be able to access the learning place and time. Whether the students are structured correctly or not, should be monitored with the questions added to the video.

\section{Edmodo}

Edmodo is a social learning management system that has unlimited storage support, easy grouping of students, planning for teaching-learning processes, managing these processes and many other features under a single platform. With Edmodo you can create discussion groups, organize surveys and give different badges to your students for their active participation. With Edmodo you can be friends with teachers from different cities all over the country, you can join different groups in the direction of your interests, so you can socialize learning more.

Edmodo can be used for the students of Flipped Teaching method lesson to participate in online diaries, online surveys and tests. Students can login to Edmodo after watching the lesson videos and write diaries that compare the information they have learned with the existing knowledge, and they can be asked to focus more on the changes in the cognitive process. An evaluation of each week's lesson and the students' achievements in the course can be monitored through the logs.

\section{Facebook Groups}

Facebook Groups have become the fastest and easiest way of communication for students today. While the Teaching method lesson Facebook group is generally used for announcements, it has become a place where all members can share freely about education and life. Course materials formed during classroom activities can also be instantly shared among these groups.

\section{Classroom Activities and Web 2.0 Applications Used}

Activities performed in the classroom may vary depending on the subject of each week. In this section, we will briefly mention the activities that can be done every week and will talk about the introduction and usage of Web 2.0 applications that can be used in these activities.

\section{Kahoot and Padlet}

It is a fact that if the students are informed with the model they are going to study throughout a semester from the beginning, it will create convenience in terms of their adaptation to the lesson. An online test with Kahoot can be performed to check the knowledge of students who are prepared for the class. Kahoot is a fun Web 2.0 application that encourages all class participation at the same time and places students in points order, focusing on short-term correct answers. The first encounter of students with Kahoot generally left positive impressions and prompted the repetition of this practice. 
Padlet is an application that enables collaborative working in online environment simultaneously. You may ask six groups of five or six students to write and answer any questions that come to their minds about Flipped Classrooms through Padlet application. At the end of each 5 minutes, each group enters the other group's wall and continues to answer the questions and ask new questions. Thus, answers to the questions in the mind of the whole class that have contributed to the wall of a group at the beginning and contributed in the other five groups can be sought. At the end this application can present all the ideas emerging on the wall.

\section{Kahoot and Piktochart}

The Kahoot application was used again to check the students' prior knowledge. After a discussion activity on 21 century skills was made, the students were divided into groups and asked how they would design an education system that focused on 21 century skills if they had possibilities as a group. The educational system designed by each group has been introduced through info graphic presentation with Piktochart. Piktochart is one of the Web 2.0 applications with a simple interface where we can prepare info graphics using ready-made templates.

\section{Socrative, Google Docs and Pictochart}

For a few weeks, students may be asked to review and advertise different web 2.0 applications to determine which applications can be used in which courses. In this direction, students may be asked to prepare for the lesson by watching video-tutorials on the course of transition from Web 1.0 to Web 2.0 first, and on the changes in user roles along with Web 2.0. A different online test application, Socrative, can be used to measure students' readiness. Socrative application is a Web 2.0 application that has a structure like Kahoot application where we can prepare online test and implement it in different competition formats. Students who compete individually with Kahoot will try to achieve success in group in Socrative application.

After checking the prior knowledge about Web 2.0, the main activity can be switched. Students may be asked individually to choose a Web 2.0 application and promote it. Google Docs can be used at this stage. At the same time, multiple people can work on a single Word document on Google Docs, and instantly see changes made. In order not to let the students choose same applications, the joint document should be prepared and filled by students. So, the problem of choosing the same applications is quickly removed. The selected Web 2.0 applications must be initially advertised on a Word document and presented as posters from the raw data by using the Piktochart application.

\section{Nearpod and Blogs}

Incoming weeks topic should be defined as teaching methods. As they have preliminary knowledge from the course of Instructional Principles and Methods about the teaching methods of the students, there will be no difficulties in preparation for the course. After the four-week Web 2.0 application introduction, the Nearpod application can be selected to show to the students that the teaching methods can be used more effectively in the context of these applications. Nearpod is an application where we can prepare interactive course contents, simultaneously share screens with students over laptop computers, tablets and smartphones and get immediate evaluation results. Two different contents for History and English courses has been prepared on Nearpod application and it can be 
emphasized how these courses can be processed with Nearpod application. At the same time, it can be shown to the students that the limitations of teaching methods in this process can be eliminated by Web 2.0 applications.

With the approach of the end of the semester, the final projects of the students have also started. The final project includes the process of designing a course in accordance with the flipped classrooms model by selecting one of the topics covered in the information technology and software course curriculum. Within the scope of the project, the students should determine their subjects and target groups, form goals and achievements, record lesson videos, design in class activities, and plan the process of measuring and evaluating. All these processes should be created with Web 2.0 applications where they can prepare different blogs. The final project of the students who are required to design a lesson with the information they have obtained during the course should be considered as the final grade for the teaching method course.

\section{Kahoot and Presentation Practices}

After the integration of technology identified as the subject of general courses, it is possible for students, before coming to class, to acquire knowledge based on the definition of technology integration, and the factors that impede technology integration and integration models. With the help of Kahoot, the level of readiness of the students is determined and the main activity can be applied. Students may be required to submit a model-based technology integration project in line with specific criteria and submit their projects to the school administration under the scenario. Projects can be graded according to the situations of convincing school management. The number of students and teachers and the school's existing facilities and budget can be given as a criterion. Prepared projects must be converted to presentation with Prezi, online PowerPoint and Piktochart.

\section{Mobile learning}

Mobile learning and Bring Your Own Device (BYOD) must be determined as a topic of another week. As it is thought today that a smartphone or portable technology is in the hands of every student at the level of higher education, mobile learning has become an increasingly popular topic. As mobile learning has been widely used in flipped classrooms, students have already had this experience from the very beginning. In this week, students can learn about mobile learning and BYOD in their preclass videos, and then as class activity - activities that increase the general cultural knowledge of students can be made. Six different titles stand out in this context. These titles are; impressive TED talks, educational films, educators who need to be followed up on social networks, documentaries on education, life and universe, educational success stories and educational books. The obtained data can be re-elaborated in the direction of teacher orientations and an important archive can be obtained at the end of the course. Prepared documents can be shared on Facebook groups and students in different groups can benefit from the data under all headings.

\section{Google Cardboard and Blippar}

Virtual and enhanced reality can be determined as a new subject. When contribution to educational research of virtual and enhanced reality is considered, it becomes important that students should obtain this knowledge. In the pre-class videos, students should be provided with information on the 
definition of virtual and enhanced reality, sample videos and differences between them. Questionand-answer activities can be held firstly to determine the readiness of the students. For experiencing both virtual reality and enhanced reality, Google Cardboard and Blippar products must be brought to class. Google Cardboard is a carton made product that allows you to experience a virtual reality experience by opening applications that are compatible with Cardboard on the smartphone. Despite the number of educational applications is low, it provides a simple, fun and economical way of experiencing virtual reality. Students should be asked to download the Blippar application on their phones for enhanced reality experience. While experiencing enhanced realism by Blippar products scanned with the Blippar application, Blippar products in Google Images provide a simple way to experience enhanced realism. Finally, students who experience virtual and enhanced reality can have a debate about how these emerging technologies can integrate into education (Serin, 2017).

\section{Dramatization}

Dramatization can be specified as the last week's topic. Dramatization is defined as the use of drama elements in drama contexts in non-drama environments. Particularly, in social issues, drama is a preferred method in order to deliver behavior to individuals. In education environments, the use of drama is also used to increase the motivation of the students and to enable them to learn in a fun way. The course has been started with Kahoot and Socrative applications so that students can focus on the lesson and increase their motivation. Both Kahoot and Socrative are some of the online testing tools which contain some game elements. After the prior knowledge is tested, as a last week activity, students may be asked to develop a drama play project that will translate the negative behaviors observed in the faculty into positive events. In this direction, the placement of cigarette butts on the floor of canteen, students' sleepy arrival to the class, problems such as weak communication between the students and administrative staff, little participation of students in social activities can be determined as a problem and a solution can be sought through drama play. The resulting ideas can be written in a Word file and shared in Facebook groups.

\section{Measurement and Evaluation}

Assessment in education is aimed at determining how much the student has attained to the learning goal in the process, what the deficiencies in the learning process are, and whether the learning system is deficient or inadequate (Başol, 2013; Güler, 2011). In general, measurement evaluation methods are divided into formative evaluation and summative evaluation (Demirel, 2004). Formative evaluation is carried out through the regular use of techniques such as learning forms, observation forms, class activities, self or peer assessment, and student development files (Worthen and Sanders, 1987). Summative evaluation is the quantification and evaluation of learning products by using measurement techniques such as written or verbal surveys, multiple choice exams, project assignments, etc. (Worthen and Sanders, 1987). By means of these methods, the progress of the learners, the way they approach the learning goal, and the difficulties they encounter in the learning process can be determined. In this process, it is very important to provide feedback to the learner regularly and to guide learning problems. Summative evaluation completes the process by using learners' exam preparation or homework during the training process used. Formative assessment, however, ensures that learners can participate effectively in the process, have the opportunity to 
practice what they have learned, and receive regular feedback in the process. In addition, formative assessment facilitates the tutor's guiding role in teaching because it spreads throughout the educational process. Because of all this, a formative evaluation approach can be adopted in the measurement and evaluation activities of flipped classrooms practice, which is an up-to-date and constructivist teaching model.

The overall assessment of the teaching method lesson can be done over 100 per semester. The highest possible score for each topic can be determined as 15 points, and the remaining 25 points are set as the general viewpoint of the teacher so that the learners can take an overall assessment of the entire course. As promised in the flipped class process, students can be presented with videos of each topic and class events can be organized for each topic. For this reason, the process of evaluation can be carried out in two stages for each topic, in-class and out-of-class. In-class and out-of-class evaluations can be assessed with a ten-point upper limit so that the weights of in-class and out-ofclass evaluations are equalized. It is believed that this has enabled the learners to keep the interest both in-class and out-of-class alive.

For out-of-class assessments, learners' can be scored by watching videos, responding to questions (if any), pre-class and post-class diaries and practice logs. In the evaluation of the activities in the classroom, evaluation can be done by observing the products of the activity, the active participation of the learners, critical, creative and reflective perspectives. With the addition of these two points, the scores obtained by the learners as a result of the process evaluations can be calculated as an evaluation score.

\section{Teacher Experience}

Flipped Classroom is a model that increases the workload of the teacher in comparison to a course with a traditional mode of operation. With this model, the course videos should be prepared for each topic, activities should be designed to determine the level of readiness of the students, class activities should be prepared for understanding and realization of the topic more deeply and product-oriented process evaluation should be used in order to make the evaluation of the whole process well. In this context, it can be said that the workload of the teacher in the classes processed especially with crowded groups is increased in proportion to the number of students.

Despite the limitations of the application, the transfer of the topic out of class and the readiness of the students before the lesson will be seen as an increase of motivation towards the lesson in both teachers and students. It will be seen that the negative effects of learning out-of-class elements are diminished when students actively take part in-class activities. In addition to all these, the interaction between the teacher and the students has increased and the activities initially done for the grades will begin to be for learning purpose over a time.

\section{Conclusion}

In this study, a number of developments in the area of flipped classroom, the power and effects of handheld technologies and programs were examined; its role and functions were explained. In the scope of the research; teaching methods / approaches which mathematics teachers used in their lectures were explored, and attempts were made to determine their views on the application of the teaching approach based on learning techniques in mathematics teaching. 
The flipped classroom approach contributes to better learning by allowing students to be more active in the process and increasing their motivation. There is an increase in the variables such as satisfaction, end of year achievement scores, or devotion to the study (Chen et al., 2014; Fulton, 2012; Goodwin and Miller, 2013; Leung et al., 2014). In addition, an important influence in functioning of the method is that the process is adopted not only by teachers but also by students. In general, innovations and developments in advanced education technologies will enable countries to benefit from each other's experiences and misconceptions, to develop multifaceted cooperation at national and international levels, to develop various projects without ignoring local conditions and possibilities, to eliminate deficiencies by applying them in schools, so successful models need to be disseminated in schools and throughout the country. The main criticism of the flipped classroom approach is that such schools are in need of well-informed and talented teachers who have taken lessons in this way. In this regard there is much work to be done in the education faculties of the universities that are training teachers of the future.

Universities prepare their students for the future. There are potential prospective teachers among these students. Therefore, for the future of the world, innovative and productive teachers should be trained and very important for the lecturers of the education faculties of the universities to teach future teachers to give lessons using 21st century curriculum and methods.

In this regard, the curricula of the education faculties should be revised, information about flipped classroom approach should be provided in training courses, and the methods and programs that can be used in practice should be handled in details.

\section{References}

Başol, G. (2013). Eğitimde ölçme ve değerlendirme. Ankara: Pegem A Yayıncılık.

Bergmann, J., \& Sams, A. (2012). Before you flip, consider this. Phi Delta Kappan, 94(2), 25-25.

Bergmann, J., \& Sams, A. (2014). Flipped learning: Gateway to student engagement. Washington DC: International Society for Technology in Education.

Bliemel, M. J. (2014). Getting entrepreneurship education out of the classroom and into students' heads. Entrepreneurship Research Journal, 4(2), 237-260.

Bretzmann, J. (2013). Flipping 2.0: Practical strategies for flipping your class. New Berlin, WI: The Bretzmann Group LLC.

Chen, Y., Wang, Y., Kinshuk \& Chen, N. S. (2014). Is FLIP enough? Or should we use the FLIPPED model instead?. Computers \& Education, 79, 16-27.

Darling-Hammond, L. (2006). Constructing 21st-century teacher education. Journal of Teacher -Education, 57(3), 300-314.

Demirel, Ö. (2004). Eğitimde program geliştirme. Ankara: Pegem A Yayıncılık.

Dewey, J. (1980). The school and society. Southern Illinois University Press.

Evseeva, A., \& Solozhenko, A. (2015). Use of flipped classroom technology in language learning. Procedia-Social and Behavioral Sciences, 206, 205-209.

Fulton, K. P. (2012). 10 reasons to flip. Phi Delta Kappan, 94(2), 20-24

Goodwin, B., \& Miller, K. (2013). Evidence on flipped classrooms is still coming in. Educational Leadership, 70(6), 78-80. 
INTERNATIONAL JOURNAL OF ACADEMIC RESEARCH IN BUSINESS AND SOCIAL SCIENCES

Vol. 9, No. 1, Jan, 2019, E-ISSN: 2222-6990 ㄷ 2019 HRMARS

Güler, N. (2011). Eğitimde ölçme ve değerlendirme. Ankara: Pegem A Yayıncılık.

ISTE (2008). ISTE standarts for students. http://www.iste.org/standards/iste-standards/ standards-for-students adresinden 15.02.2016 tarihinde edinilmiştir.

Kotluk, N., \& Kocakaya, S. (2015). 21. yüzyıl becerilerinin gelişiminde dijital öykülemeler:

Ortaöğretim öğrencilerinin görüşlerinin incelenmesi. Eğitim ve Öğretim Araştırmaları Dergisi, 4(2), 354-363.

Lage, M., Platt, G., \& Treglia, M. (2000). Inverting the classroom: A gateway to creating An inclusive learning environment source. Te Journal of Economic Education, 31(1), 30-43.

Leung, J. Y. C., Kumta, S. M., Jin, Y., \& Yung, A. L. K. (2014). Short review of the flipped classroom approach. Medical Education, 48(11), 1127-1127.

Mason, G. S., Shuman, T. R., \& Cook, K. E. (2013). Comparing the effectiveness of an inverted classroom to a traditional classroom in an upper-division engineering course. Education, IEEE Transactions on, 56(4), 430-435.

Nerguizian, V., Mhiri, R., Mounier, C., Lemieux, D., \& Dahmane, A. O. (2014). Flipping from flipped classroom to multimodal mobile learning (MML). International Journal of Teaching and Education, 2(4), 53-66.

Obradovich, A., Canuel, R., \& Duffy, E. P. (2015). A survey of online library tutorials:

guiding instructional video creation to use in flipped classrooms. The Journal of Academic Librarianship, 41(6), 751-757.

O'Flaherty, J., \& Phillips, C. (2015). The use of flipped classrooms in higher education: A scoping review. The Internet and Higher Education, 25, 85-95.

P21. (2009). Framework for 21st century learning. http://www.p21.org/our-work/p21framework adresinden 15.02.2016 tarihinde edinilmiştir.

Phillips, D. C. (1995). Te good, the bad, and the ugly: Te many faces of constructivism. Educational Researcher, 5-12.

Serin, H. (2015). The role of technology in whole class teaching. IJSSES Journal, 2(1), 2528.

Serin, H. (2017). Augmented Technologies in the education: AR apps. Journal of Educational Sciences \& Psychology, 7(2), 04-16.

Strayer, J. (2012). How learning in an inverted classroom influences cooperation, innovation and task orientation. Learning Environments Research, 15(2), 171-193.

Taşkıran, A., Koral, E., \& Bozkurt, A. (2015). Artırılmış Gerçeklik Uygulamasının Yabancı Dil Öğretiminde Kullanılması. Akademik Bilişim Kongresi.

Temizyürek, F., \& Ünlü, O. N. A. (2015). Dil Öğretiminde Teknolojinin Materyal Olarak Kullanımına Bir Örnek: "Flipped Classroom” (The Use of Technology in Language Teaching Material as an Example:" Flipped Classroom"). Doi: 10.14686/BUEFAD. 2015111015. BARTIN ÜNIVERSITESI EĞITIM FAKÜLTESI DERGISI, 4(1), 64-72.

Turan, Z., \& Göktas, Y. (2015). A New Approach in Higher Education: The Students. Views on Flipped Classroom Method', Yükseköğretim ve Bilim Dergisi, 5(2), 156-164.

Tucker, B. (2012). Te flipped classroom. Education Next, 12(1), 82-83.

Von Glasersfeld, E. (1989). Cognition, construction of knowledge and teaching. 
INTERNATIONAL JOURNAL OF ACADEMIC RESEARCH IN BUSINESS AND SOCIAL SCIENCES Vol. 9, No. 1, Jan, 2019, E-ISSN: $2222-6990$ @ 2019 HRMARS

Synthese, 80(1), 121-140.

Worthen, B. R. ve Sanders, J.R. (1987). Educational Evaluation: Alternative Approaches and Practical Guidelines.

YÖK (Yükseköğretim Kurulu). (2007). Eğitim fakültesi öğretmen yetiştirme lisans programları. 13 May 2017, Retrieved from https://www.yok.gov.tr/documents/10279/30217/ E\%C4\%9E\%C4\%B0T\%C4\%BOM+FAK\%C3\%9CLTES\%C4\%B0\%20\%C3\%96\%C4\%9ERETMEN+YET \%C4\%B0\%C5\%9ET\%C4\%BORME+L\%C4\%BOSANS+PROGRAMLARI.pdf/054dfc9e-a753-42e6a8ad-674180d6e382. 